\title{
An Exploration of the Measurement of Relational Capital in Supply Chains
}

\author{
Barbara Ocicka \\ Collegium of Business Administration, Department of Logistics \\ SGH Warsaw School of Economics, al. Niepodległości 162, 02-554 Warsaw, Poland \\ Email: barbara.ocicka@sgh.waw.pl (Corresponding Author) \\ Grażyna Wieteska \\ Faculty of Management, Department of Logistics \\ University of Lodz, Matejki 22/26, 90-237 Łódź, Poland \\ Email: grazyna.wieteska@uni.lodz.pl
}

\begin{abstract}
The aim of the paper is to identify and systemise dimensions and measures that can be used to evaluate buyersupplier relational capital (RC). The authors used a literature review methodology composed of the following phases: question formulation, keyword search in databases, screening and analysis of articles. As a result, 44 articles were selected and finally analysed in detail. It was found that several theories can help to explain how buyer-supplier relationships contribute to a company's value and competitive advantage. Furthermore, $\mathrm{RC}$ as an element of social capital deserves more investigation in a supply chain management context. Accordingly, to date there has been no relevant in-depth studies exploring the measurement of relational capital in supply chains. On the base of the review of research articles published between 2004 and 2018, the list of items used by researchers to measure the relational capital was explored. Then, authors proposed a construct for relational capital consisting of 5 items such as: trust, close interaction, respect, reciprocity and commitment, that were shortly discussed. Taking them all into account, an authorial definition of supply chain relational capital was proposed. Although, the final results contribute to the study of RC measurement within buyer-supplier relationships in supply chains, the analysis still has some shortcomings that need to be addressed in further literature studies and empirical research.
\end{abstract}

Keywords: buyer-supplier relationships, relational capital measurement, supply chain management

\section{INTRODUCTION}

Facing the enormous challenges and managing the complexities in global business environment of the $21^{\text {st }}$ century, companies more and more often recognize the need for developing strong relationships with their supply chain partners (Whipple et al., 2015, p. 3). Christopher (2011) developed the definition of supply chain management that sheds light on the management of upstream and downstream relationships with suppliers and customers in order to deliver superior customer value at less cost to the supply chain as a whole (Christopher, 2011, p. 3). In today's highly competitive markets, the management of buyer-supplier relationships is crucial for achieving and maintaining competitive advantage. As a result, more and more leading firms perceive relational capital as a resource of strategic importance.
Based on the value management approach, intangible assets become key companies' resources and the evaluation of a firm's real value is based on the shift from the previous evaluation of tangible assets to the expression of intangible assets. Relational capital is a kind of intangible asset that represents "the portion of a company's market value that is attributable to its portfolios of business relationships" and its valuation is an important research topic (Léger, 2010, p. 406). It was confirmed in the literature that relational capital has a positive influence on the firms' and supply chain's performance (Ciszewska-Mlinarič et al., 2012; Johnson et al., 2013). On the other hand, Villena et al. (2011) identified the paradox that relational capital can improve as well as hurt performance. Based on this duality, the authors identified that collaboration between supply chain entities should not become too extreme, because it can inhibit business partners' capabilities to effectively adapt to changing market needs (Villena et al., 2011, p. 571). Both aspects, the measurement of relational capital and its influence on performance, have been mostly derived from the qualitative evaluation based on the Likert scale (from 1 to 5 or 7) regarding items used by the authors in proposed models. Additionally, some authors developed conceptual models, in which relational capital has an important mediating and moderating role, like a bridge between supplier development and relationship benefits (Blonska et al., 2013). It was also confirmed that supplier integration and supplier closeness are positively related to increased stock of relational capital in strategic buyersupplier relationships (Lawson et al., 2008).

Because of the pivotal strategic role of supply chains relationships, which lead to a competitive advantage, authors of this article believe that there is a need to carry out more research focused on managing and measuring relational capital. Furthermore, they found that there were no relevant studies exploring the measurement of relational capital in supply chains, therefore the discussion is focused on this research gap. The aim of the paper is to identify and systemise dimensions and measures that can be used to evaluate buyer-supplier relational capital (RC). Firstly, the methodology is presented. Then, theoretical foundations for the study are derived from the theories of socialization, social capital, resource-based view, resource dependence and dynamic capabilities building. Next, the study investigates definitions of relational capital in supply chain perspective. 
Finally, it lists most common items used for RC measurement. This approach would be helpful for supply chain managers in evaluation of relational capital. Its development might transform supply chain relationships to become a source of profit and competitive advantage. The results contribute to the study of value creation within buyersupplier relationships in supply chains.

\section{METHODOLOGY}

The paper is based on a desk research. The authors used a literature review methodology applied from Tranfield $e t a l$. (2003). The review process consisted of the following phases:

1. Question formulation;

2. Keyword search in databases;

3. Screening (removing duplicates, closer inspection, checking cited articles);

4. Analysis of articles.

The main research questions were formulated as follows: What are the main elements of relational capital in a supply chain? What are the financial and non-financial measures for supplier-buyer relational capital?

In the second phase, the two leading providers of research databases were used EBSCOhost Online Research Databases, Emerald Insight: In each database the two searches were conducted applying the following search terms and restrictions:

1. Search terms: "relational capital" and "supply chain", a restriction: occurrence in abstract;

2. Search terms: "relational capital" and "supplier", a restriction: occurrence in abstract.

The number of papers gathered in the second phase (keyword search in databases) was 175 (Table 1). The numbers of selected papers during the third phase consisting of four screening stages are presented in Table 2.

Table 1. The results of the second phase - keyword search in databases

\begin{tabular}{ccc}
\hline \multirow{2}{*}{$\begin{array}{c}\text { Phase } \\
\text { Description }\end{array}$} & Database & $\begin{array}{c}\text { Output } \\
\text { (Number of } \\
\text { Papers) }\end{array}$ \\
\hline \multirow{2}{*}{$\begin{array}{c}\text { searching the } \\
\text { papers in } \\
\text { databases }\end{array}$} & Search 1 in EBSCOhost & 38 \\
\cline { 2 - 3 } & Search 1 in Emerald & 19 \\
\cline { 2 - 3 } & Search 2 in EBSCOhost & 84 \\
\hline
\end{tabular}

Source: own elaboration.

The first three screening phases caused a reduction in the number of articles, while the fourth phase, due to the checking cited articles, caused an increase in the number of articles by one. The final output from the screening phases was 44 articles that has been subjected to the final phase, which is a detailed analysis. In the next part of this section the following statistics will be presented:

- Year-wise distribution of the publications;

- The distribution of countries represented by the authors of the publications;

- Journal-wise distribution of the publications;

- Methodologies used in the publications;

- The research perspective of surveys and case studies;

- The distribution of types of researched sectors.
Figure 1 represents the year-wise distribution of the publications. The data indicates that the concept of relational capital emerged in supply chain literature around 2004.

Table 2. The results of the third phase - screening

\begin{tabular}{lcc}
\hline Phase Description & Database & $\begin{array}{c}\text { Output } \\
\text { (Number of } \\
\text { Papers) }\end{array}$ \\
\hline $\begin{array}{l}\text { Screening 1 } \\
\text { recognizing papers that } \\
\text { are related to the } \\
\text { relational capital in } \\
\text { supply chain } \\
\text { management }\end{array}$ & 110 \\
\cline { 2 - 2 } $\begin{array}{l}\text { Screening } 2 \\
\text { removing duplicates } \\
\text { between search 1 and } \\
\text { search 2 }\end{array}$ & EBSCOhost & 16 \\
\hline $\begin{array}{l}\text { Screening } 3 \\
\text { closer inspection } \\
\text { (selecting articles that } \\
\begin{array}{l}\text { define the measurement } \\
\text { of relational capital) }\end{array}\end{array}$ & $\begin{array}{c}\text { Emerald } \\
\text { Screening } 4 \\
\text { checking cited articles }\end{array}$ & Emerald \\
\hline
\end{tabular}

Source: own elaboration.

\section{Year-wise Distribution of Publications}

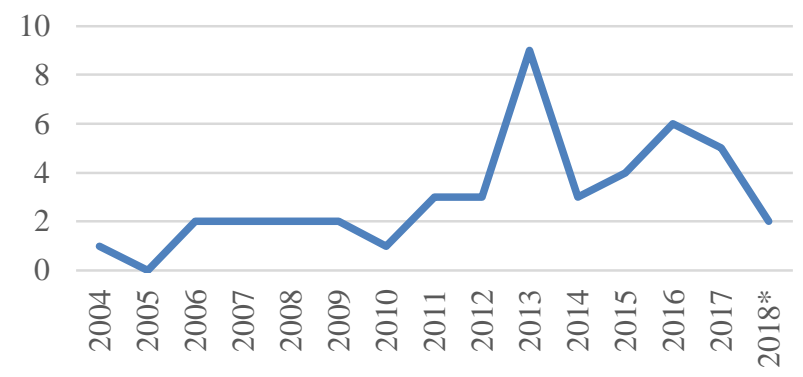

Figure 1. Year-wise distribution of publications (* up to the end of June 2018) Source: own elaboration.

In 2013 there is an increase in the number of publications on relational capital in supply chain. Since this study has been conducted in the middle of 2018, we expected that the number of the publications in the full year 2018 would be similar to the 2016 and 2017 years or even higher. Despite the fact that the number of publications on RC in supply chain is relatively low, because it did not exceed ten per year, it is assumed that interest in this area will increase in the next decade.

Figure 2 shows the distribution of countries represented by the authors of the publications. The dominant country is USA, whose representatives wrote 15 publications. Next country is UK with 10 publications. There is also one paper written by scientists from Poland and Slovenia. Half of analysed articles were written by authors from one country. The other half is written by authors from two countries, what indicates a high degree of internationalization of the research on relational capital in the supply chain. 
The Distribution of Countries Represented by the Authors of the Publications

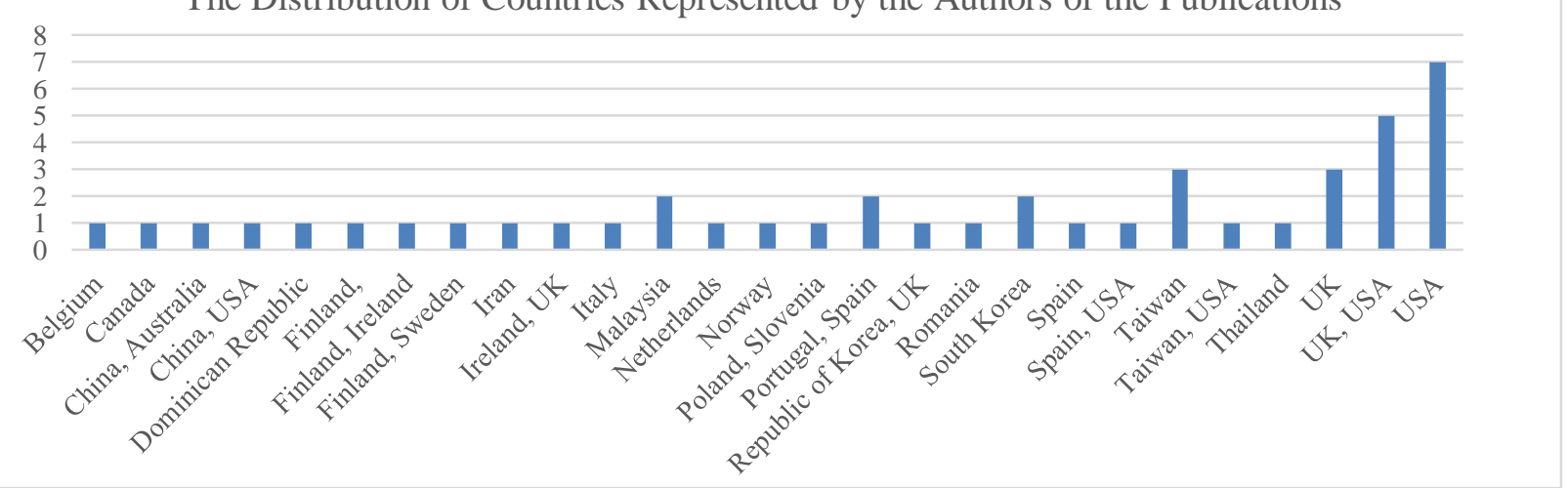

Figure 2. The distribution of countries represented by the authors of the publications Source: own elaboration.

Figure 3 presents the journal-wise distribution of the 44 publications that have been subjected to the final analysis. Since no restrictions were placed on the source of the article, one paper was published in proceedings. The rest of publications appeared in 28 different journals. None of journals significantly dominates in the publication of articles about relational capital in supply chains. The maximum number of publications in a given distribution is four. This situation applies to the International Journal of Operations \& Production Management as well as to the Journal of Operations Management. They contribute to the field of operations and supply chain management.

Considering Table 3, it is evident that survey has been the main focus of researchers within the area of relational capital in supply chains. In each case, authors provided several hypothesis and used structural equation modelling. Case studies were written based on data collected during indepth interviews. Finally, literature review has not been a frequent methodology. This paper fills this gap and presents the first systematic literature review on the issue of relational capital in supply chains.

Table 3. Methodologies used in the publications

\begin{tabular}{cccc}
\hline \multicolumn{4}{c}{ Methodologies } \\
\hline Survey & Framework & $\begin{array}{c}\text { Case } \\
\text { Study }\end{array}$ & $\begin{array}{c}\text { Literature } \\
\text { Review }\end{array}$ \\
\hline 36 & 6 & 4 & 1 \\
\hline
\end{tabular}

Source: own elaboration.

The following respondents dominated among the respondents: $\mathrm{CEO}, \mathrm{COO}$, supply chain director, purchasing manager. In general, they represented management, procurement, production but also R\&D and marketing. Thus, both the departments responsible for the contact with suppliers and the departments cooperating with clients took part in the studies. This is confirmed by the Table 4 that presents the perspective of analysed studies.

Table 4. The research perspective of surveys and case studies

\begin{tabular}{lc}
\hline Perspective & No. of Papers \\
\hline Single company perspective & 33 \\
\hline Dyadic perspective (company and suppliers) & 4 \\
\hline $\begin{array}{l}\text { Triadic perspective (company, suppliers and } \\
\text { clients) }\end{array}$ & 3 \\
\hline
\end{tabular}

Source: own elaboration.
As a rule, single companies and their view on supplier relationships were examined (33 papers). However, it happened that two parties (supplier and buyer) participated in the same research or even the three types of supply chain links: the company, its suppliers and its clients. According to the statistics, the dyadic perspective related four publications and the triadic perspective concerned three papers. Such data show that the papers related to the dyadic or triadic perspective is still scarce.

The Table 5 presents the distribution of types of researched sectors.

Table 5. The distribution of types of researched sectors

\begin{tabular}{lc}
\hline Type of Sector & No. of Papers \\
\hline Manufacturing & 29 \\
\hline Manufacturing and Services & 8 \\
\hline Services & 2 \\
\hline Distribution & 1 \\
\hline
\end{tabular}

Source: own elaboration.

The statistics show that 32 papers studied one sector. Most authors examined manufacturing companies. Only one paper referred to the distribution sector. The next 8 publications concerned simultaneously two sectors: manufacturing and services. The data indicate that future research should focus on a comparison of three different sectors: manufacturing, distribution and services.

\section{THEORETICAL FOUNDATIONS FOR A RELATIONAL CAPITAL RESEARCH}

In building the foundations of the study, the authors of this article analysed a set of theories, theoretical frameworks and complementary approaches used in 44 articles that have been subjected to the final analysis, as Figure 4 presents. In most of the publications (19), the social capital theory was used as a primary theoretical foundation of research methodology. As the complementary theoretical concepts, the authors of the analysed publications took into consideration theories of transaction costs (2), knowledgebased view (2), resource dependence (2), socialization (3), capabilities building (4), intellectual capital (7) and resourcebased view (7). The significance of other theories mentioned altogether in 9 papers was marginal. 


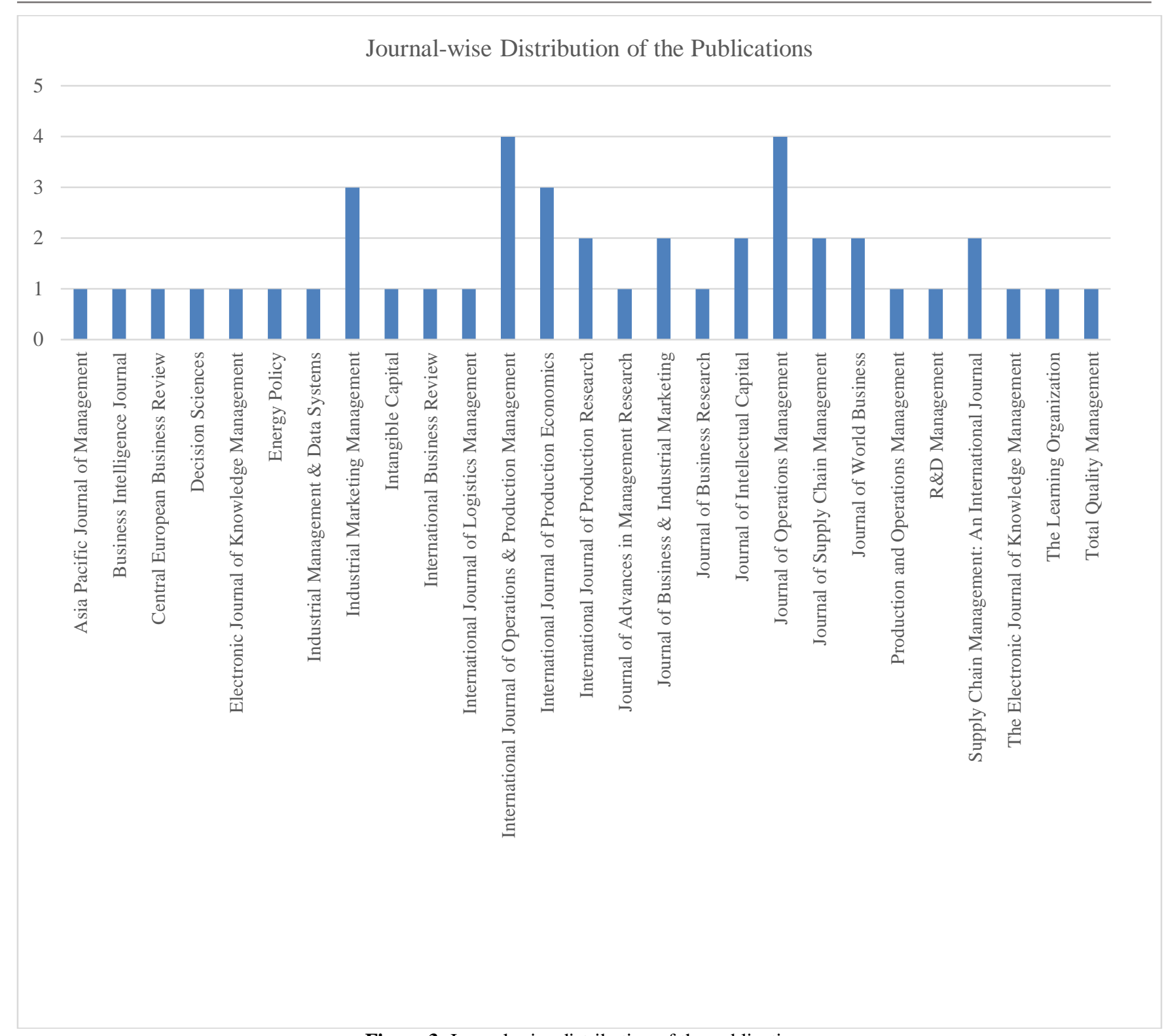

Figure 3. Journal-wise distribution of the publications Source: own elaboration.

The roots of research on the inter-organizational processes that create relational value in supply chains are derived from the theory of socialization. Supply chain socialization is defined as "a process by which individuals in a buyer-supplier engagement acquire knowledge of the other enterprise's social value and norms" (Cousins et al., 2006, p. 853). Cousins et al. (2006) propose proactive socialization process between individuals as a means to buyer-supplier relationships success and find that socialization contributes to the creation of relational capital and the achievement of improved relationships outcomes. Operations and supply chain management research highlights the importance of various socialization mechanisms: development of common goals, values and trust, building of personal familiarity, the advanced interaction and communication among organizational members as well as between organizations, improved problem solving within network of organizations, that can be divided into formal and informal mechanisms (Cousins et al., 2006; Jia et al., 2016; Aaltonen and Turkulainen, 2018). The just mentioned authors argue that socialization process is critical for building and managing relational capital in buyer-supplier relationships.

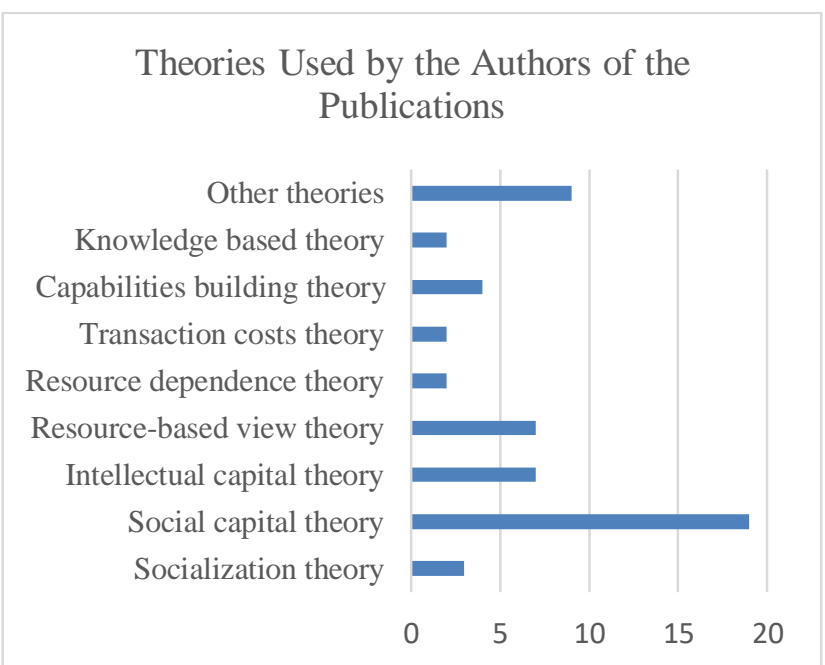

Figure 4. Theories used by the authors of the publications. Source: own elaboration. 
Social capital theory provides the primary theoretical basis for the authors' studies focused on relational capital in the context of supply chain management. Social capital is defined as "the sum of actual and potential resources embedded within, available through, and derived from the network of relationships possessed by an individual or social unit" and has three dimensions: relational, cognitive and structural (Nahapiet and Ghoshal, 1998). Prior literature has examined social capital among individuals, work groups and interorganisational units (Preston et al., 2017, p. 250). There are some studies indicating that the relational capital is most important from these three aforementioned dimensions of social capital (Chen et al., 2006). There is a chance for the companies to achieve a relational rent that is "a supernormal profit jointly generated in an exchange relationship that cannot be generated by either firm in isolation and can only be created through the joint idiosyncratic contributions of the specific alliance partners" (Dyer and Singh, 1998, p. 662). According to Cousins et al. (2006), both buyers and suppliers can use relational capital to help build knowledge sharing and relationship-specific investments to generate relational rents. Many authors underline that different dimensions of social capital are useful explanatory constructs and deserve more investigation in a supply chain management context, indicating simultaneously support for the application of social capital theory to buyer-supplier relationships (Krause et al., 2007; Cousins et al., 2006). Besides, it was also stressed that dimensions of social capital within strategic buyer-supplier relationships have been relatively underexplored in literature (Carey et al., 2011, p. 278).

Extending the application of the social capital theory to buyer-supplier relationships, the authors focus on the concept from a resource-based view (RBV) perspective. The RBV theory treats organisations as "unique bundles of accumulated tangible and intangible resource stocks, including specific internal capabilities, processes and procedures, and routines that are linked to or are controlled by the organization" (De Clercq and Sapienza, 2006). Relational capital theory extends the RBV to the interorganisational context (Jer et al., 2017, p. 129). Relational capital is a kind of more and more important intangible asset, as firms are becoming increasingly dependent on a network of business partners to deliver value in supply chains (Léger, 2010, p. 406). Combining the resource-based view of the firm and the relational view, it should be outlined that resources can span an organization's boundaries and additionally, can be embedded within interorganisational collaborative processes (Dyer and Singh, 1998). Furthermore, "specific resources and capabilities that are sources of competitive advantage may result from processes of cooperation with external partners" (Ciszewska-Mlinarič et al., 2012, p. 29), e.g. relationshipspecific investments can enhance relationship learning capabilities and as a result, joint competitive advantage of the engaged parties (Chang and Gotcher, 2007). It should be noticed, that research has been changed from a static view to a more dynamic focus on restructuring resources bundles to accelerate strategic change and what more, its speed depends on the dynamic capabilities to restructure internal and external resources (Yi et al., 2016, p. 437).

Considering the development of relationships with external parties, the resource dependence theory (RDT) should be taken into account. It highlights that a key element of an organisation's success is "the ability to acquire and maintain resources" (Pfeffer and Salancik, 2003, p. 2), emphasising the role of suppliers providing resources that are not available within the firm (Pfeffer and Salancik, 2003; Kulangara et al., 2016). RDT refers to the socialization mechanisms as effective methods to manage the interdependencies between the companies, e.g. trust can reduce uncertainty and opportunism between them (Kulangara et al., 2016, p. 1606).

To conclude, the authors of this article suggest that theories of socialization, social capital, resource-based view, resource dependence and dynamic capabilities building are the most helpful in examining relational capital development in the context of supply chain management.

\section{THE DEFINITIONS OF RELATIONAL CAPITAL}

In the nineties of the $20^{\text {th }}$ century, the term "relational capital" appeared as part of the definition of "social capital". In the very often quoted framework of Nahapiet and Ghosal (1998) the social capital consists of the three following dimensions: cognitive capital, structural capital and relational capital.

Table 6. Examples of relational capital definition

\begin{tabular}{|c|c|}
\hline Authors (year) & Definition \\
\hline $\begin{array}{l}\text { Cousins et al. } \\
(2006)\end{array}$ & $\begin{array}{l}\text { Supply chain relational capital as the } \\
\text { configuration and social structure of the } \\
\text { group through which resources are } \\
\text { accessed The level of } R C \text { is assessed by } \\
\text { the degree of mutual respect, trust, and } \\
\text { close interaction that exists between the } \\
\text { partner firms. }\end{array}$ \\
\hline $\begin{array}{l}\text { Chen, } \\
\text { et al. (2006) }\end{array}$ & $\begin{array}{l}\text { Relational capital as the stocks of } \\
\text { connections, interactions, relationships, } \\
\text { linkages, closeness, goodwill and loyalty } \\
\text { between a firm and its upstream suppliers, } \\
\text { downstream clients, strategic partners or } \\
\text { other external stakeholders. }\end{array}$ \\
\hline $\begin{array}{l}\text { Krause et al. } \\
(2007)\end{array}$ & $\begin{array}{l}\text { Relational capital represented as the } \\
\text { years of the buyer-supplier relationship and } \\
\text { the dependency of the buyer and the } \\
\text { supplier to the relationship. }\end{array}$ \\
\hline $\begin{array}{l}\text { Hammervoll } \\
\text { (2011) }\end{array}$ & $\begin{array}{l}\text { Relational capital is the sum of goodwill, } \\
\text { respect and trust between buyer and seller. }\end{array}$ \\
\hline $\begin{array}{l}\text { Mousavi and } \\
\text { Takhtaei (2012) }\end{array}$ & $\begin{array}{l}\text { Relational capital is defined as all } \\
\text { resources linked to the external } \\
\text { relationships of the firm with customers, } \\
\text { suppliers or partners in research and } \\
\text { development. }\end{array}$ \\
\hline $\begin{array}{l}\text { Kohtamäki et al. } \\
\text { (2013) }\end{array}$ & $\begin{array}{l}\text { Relational capital as a form of social } \\
\text { capital embedded in a single business } \\
\text { relationship that includes dimensions such } \\
\text { as trust, open interaction and a sense of } \\
\text { shared destiny between the supplier and } \\
\text { the customer. }\end{array}$ \\
\hline $\begin{array}{l}\text { Preston et al. } \\
(2017)\end{array}$ & $\begin{array}{l}\text { Buyer-supplier relational social capital } \\
\text { is defined as the degree to which the } \\
\text { supplier and distributor have mutual trust } \\
\text { and shared norms. }\end{array}$ \\
\hline
\end{tabular}

Source: own elaboration.

The first definitions of the relational capital (RC) refer 
to the close personal relationships that are developed on the base of trust, obligation and reciprocity (Granovetter, 1992; Nahapiet and Ghoshal, 1998; Kale et al., 2000). This approach was generally accepted and exploited in consecutively appearing articles (Youndt et al., 2004; Inkpen and Tsang, 2005; Capello and Faggian, 2005; Villena et al., 2011). In the meantime, new terms that include relational capital issue have emerged, as for example "relational investment" (Léger, 2010) or "relational capital skill" (Hsu et al., 2011).

At the beginning of the 21st century, relational capital started to be recognised as an important element of supplierbuyer partnership and supply chain management. The analysis of the literature allowed to identify the key definitions in this regard (Table 6). Such elements of relationship as trust, loyalty, goodwill, or respect also appear in these definitions but this time they are mutually built through the close cooperation between supply chain links. Definitions of relational capital in supply chain refer to both upstream suppliers and downstream clients as well as to the various aspects like quality of relationship (trust, respect, shared norms and destiny), configuration and social structure, supplier-buyer interactions along with connections and dependences, further knowledge transfer and resources involved in R\&D.

Considering the results of the literature review, there are authors, who in a definition of relational capital, go beyond the interactions between firms and refer to the other stakeholders. Capello (2002) includes company interactions with institutions and research centres, whereas Youndt et al. (2004) cover the cooperation with government and industry associations.

Eventually, some similarities between available definitions of relational capital can be noticed. First, the essence of the length of the relationship is often underlined (Krause et al., 2007; Villena et al., 2011; Lee, 2015). Here, a long term cooperation can be regarded as a base for building the relational capital. Further, the importance of the intensity of relationship is present (Capello, 2002) and degree/level of the arising elements of relational capital e.g. trust, respect (Kale et al., 2000; Preston et al., 2017). Relational capital definitions also concern the issue of resource management (Youndt et al., 2004; Mousavi and Takhtaei, 2012) and the aspect of social/relational structures (Cousins et al., 2006; Huikkola et al., 2013). The relational capital is considered as a source of benefits too (Petersen et al., 2008). For example, Lee (2015) emphasises in a definition of relational capital the importance of $\mathrm{RC}$ for the reduction of transaction costs, whereas Lorenzoni and Lipparani (1999) highlight the influence of RC on growth and innovativeness.

\section{DISCUSSION ON THE MEASUREMENT OF RELATIONAL CAPITAL IN SUPPLY CHAIN}

Most of analysed articles provide a research framework that involve relational capital issues. The developed theoretical models include RC in a form of a construct which is usually defined by several observable indicators. In all cases, these items are measured using a five or seven point
Likert scale. This means that these surveys are based on the respondents' opinions and its qualitative measurement. The in-depth literature review allowed to recognise the most often used components. The outcome of the analysis is presented in Table 7.

There were also other items proposed in the conceptual models developed by authors, such as: friendship (Kale et al., 2000; Carey et al., 2011; Villena et al., 2011; Roden and Lawson, 2014; Villena and Craighead, 2017), fairness (Kohtamäki et al., 2013), family like atmosphere (Lee, 2015), length of the relationship in years (Krause et al., 2007), long-term partnership (Lee, 2015), expectation the relationship to continue for a long time or relationship as a long-term alliance (Jer et al., 2017), not misleading partner (Kulangara et al., 2016), communication (Sambasivan, 2013), satisfaction (Mubarik et al., 2016), avoiding exercising power in the relationship (Preston et al., 2017), similar approach in fostering teamwork between one antoher (Preston et al., 2017), similar pattern on how to best cooperate with each other (Preston et al., 2017), compatibility of goals and objectives (Jer et al., 2017), shared destiny (Huikkola et al., 2013), obligation, identification and norms (Nahapiet and Ghoshal, 1998; Johnson et al., 2013), goodwill and prior beliefs (Hammervoll, 2011), network relational embeddedness (Preston et al., 2017), socialization (Yim and Leem, 2013), buyer and supplier dependency (Krause et al., 2007), financial resources (Léger, 2010; Hammervoll, 2011). Although, the aforementioned mentioned elements characterize meaningful aspects of relationship management within supply chain management, other essential items were chosen as a reference due to the higher frequency of their usage in reviewed models presented in research papers published in the period 2004-2017.

According to the results, trust is in first place. There are authors who consider in their frameworks a mutual trust (Nahapiet and Ghoshal, 1998; Kale et al., 2000; Carey et al., 2011) and those who adopt one-sided trust, e.g. trustworthy supplier or customer (Kulangara et al., 2016; Jer et al., 2017). Trust occurs usually as a single research item. However, in some papers it is developed into several components (Mubarik et al., 2016, Verwaal, 2017) with reference to the previous works, like Crosby et al. (1990), or Morgan and Hund (1998). In this case, trust is defined using not only qualitative indicators (e.g. reliance on a partner, helpfulness of a partner), but is also perceived through the prism of quantitative aspects like meeting agreed requirements by a partner (i.e. providing safe materials).

The second item is a close interaction. Close interaction between partners results in learning and exchange of information and know-how, whereas one of its enablers is an alignment of buyer's and supplier's interests (Kale et al., 2000). Cousins et al. (2006) follow Gupta and Govindarajan (2000) in understanding the interactions as a part of socialisation that leads to "the building of personal familiarity, improved communication, and problem solving". Kale et al. (2000), Lawson et al. (2008) consider the need of personal interactions at multiple levels. Carey et al. (2011) regard social interaction ties as "a conceptualisation of structural capital" that can be strengthened by personal contacts, direct experiencing and getting to know a partner during social events or building inter-organisational teams. Verwaal (2017), following 
Nielson's work (1998), connects closeness with a long cooperation time and extensiveness of relationship. The extensiveness is understood as "interactions among several functional areas and the emergence of strong personal relationships between individuals in the two companies" and may be strengthened by "mutual problem solving and informal adaptations" (Nielson, 1998).

Table 7. List of items for RC measurement in the research papers between 2004-2017

\begin{tabular}{|c|c|c|}
\hline Item & $\begin{array}{l}\text { Number of } \\
\text { Occurrences }\end{array}$ & $\begin{array}{l}\text { Research Papers in the } \\
\text { Period 2004-2017 }\end{array}$ \\
\hline Trust & 20 & $\begin{array}{l}\text { Cousins et al. (2006), Chang } \\
\text { and Gotcher (2007), Lawson et } \\
\text { al. (2008), et al. (2008), Villena } \\
\text { et al. (2011), Hammervoll } \\
\text { (2011), Carey et al. (2011), } \\
\text { Sambasivan et al. (2013), Yim } \\
\text { and Leem (2013), Johnson et } \\
\text { al. (2013), Kohtamäki et al. } \\
\text { (2013), Huikkola et al. (2013), } \\
\text { Blonska et al. (2013), Roden } \\
\text { and Lawson (2014), Lee } \\
\text { (2015), Mubarik et al. (2016), } \\
\text { Kulangara et al. (2016), } \\
\text { Verwaal (2017), Preston et al. } \\
\text { (2017), Villena and Craighead } \\
\text { (2017), Ruy et al. (2017) }\end{array}$ \\
\hline $\begin{array}{c}\text { Close } \\
\text { interaction }\end{array}$ & 11 & $\begin{array}{l}\text { Carey, Lawson and Krause } \\
\text { (2011), Cousins et al. (2006), } \\
\text { Chang and Gotcher (2007), } \\
\text { Lawson et al. (2008), Petersen } \\
\text { et al. (2008), Villena et al. } \\
\text { (2011), Huikkola et al. (2013), } \\
\text { Roden and Lawson (2014), } \\
\text { Villena and Craighead (2017), } \\
\text { Verwaal (2017), Preston et al. } \\
\text { (2017) }\end{array}$ \\
\hline Respect & 9 & $\begin{array}{l}\text { Cousins et al. (2006), Lawson } \\
\text { et al. (2008), Petersen et al. } \\
\text { (2008), Carey et al. (2011), } \\
\text { Villena et al. (2011), Kohtamäki } \\
\text { et al. (2013), Roden and } \\
\text { Lawson (2014), Lee (2015), } \\
\text { Villena and Craighead (2017) }\end{array}$ \\
\hline Reciprocity & 7 & $\begin{array}{l}\text { Carey et al. (2011), Villena et } \\
\text { al. (2011), Roden and Lawson } \\
\text { (2014), Blonska et al. (2013), } \\
\text { Kohtamäki et al. (2013), Yim } \\
\text { and Leem (2013), Villena and } \\
\text { Craighead (2017) }\end{array}$ \\
\hline Commitment & 5 & $\begin{array}{l}\text { Hammervoll (2011), Blonska et } \\
\text { al. (2013), Sambasivan et al. } \\
\text { (2013), Yim and Leem (2013), } \\
\text { Mubarik et al. (2016) }\end{array}$ \\
\hline
\end{tabular}

Source: own elaboration.

The third item is mutual respect that may characterise the relationship between the partners at multiple levels of both organisations. There is a strong mutual confidence that no party will exploit others' vulnerabilities even if there is an opportunity to do so (Sabel, 1993; Kale et al., 2000). Mutual respect depends on the length of relationships and the strength of buyer-supplier dependence.

The fourth item called reciprocity is perceived as a cornerstone of cooperative exchange relationships (Hoppner and Griffith, 2011). It generally refers to the social norm that an action performed by one party requires a compensating movement by the other (Blonska et al., 2013). As an example, when buyers invest some assets and make an effort to strategic relationships with suppliers, they expect their suppliers to make similar investments. On the one hand, partners work together to achieve mutual benefits, share risk and solve problems within the collaboration development. Reciprocity means that partners consider each other's interests when problems arise (Kohtamäki et al., 2013). But on the other hand, strong reciprocity norms might develop obligations that "commit resources and constrain choices beyond what would be optimal" (Villena et al., 2011, p. 565).

Different dimensions of commitment as an item have been considered so far. A very interesting approach referring to psychological commitment was presented by Hammervoll (2011). On the one hand, it was defined in terms of choosing other supply-chain partners than the biggest in the industry, following Fichman's and Levinthal's opinion (1991) and on the other hand, as a psychological resistance to change, following Crosby and Taylor (1993). Finally, the company's willingness to change its preference for collaborating with a supply chain partner and its beliefs about a supply chain partner was measured (Hammervoll, 2011, p. 274). Within buyer-supplier relationship management, commitment might be perceived as suppliers' predisposition to remain in the relationship due to their positive affect, feeling of unity or obligation and emotional attachment to the buyer (Blonska et al., 2013; Palmatier et al., 2007), especially in a long-term perspective.

With regard to the analysis carried out so far, the following definition can be proposed:

Supply chain relational capital is an intangible asset created together by suppliers and customers through the development of a relationship based on mutual trust, respect, close interaction, reciprocity and commitment, used as a source of competitive advantage.

The definition of supply chain relational capital presented above brings into the discussion the following issues:

1. Significance of particular items for the relational capital construct.

2. Measurement of relational capital as an intangible asset in supply chains.

3. Importance of RC as a source of competitive advantage in perspective of different strategies, e.g. sustainable, innovative and resilient supply chains.

The proposed definition is based on most common characteristics. It can be used to build theoretical models that analyse dependencies between relational capital and other items related to supply chain management. In these models, the construct of relational capital can be measured using a qualitative or quantitative approach. The latter will be discussed in the next section of this paper. According to the literature review, researchers have been following only qualitative indicators so far.

The influence of relational capital on firms' competitive advantage is multidimensional and depends on the supply chain strategy. Lee (2015) stressed that RC plays 
an important role for operational as well as environmental performance within green supply chain management. Many authors highlighted the significance of relational capital as a facilitator of knowledge transfer, joint learning and collaborative innovation development in supply chains (Chen et al., 2006; Dorrego et al., 2013; Huikkola et al., 2013; Kohtamäki et al., 2013; Preston et al., 2017). Furthermore, the importance of RC was also recognised for building supply chain resilience (Johnson et al., 2013).

\section{CONCLUSIONS}

It was confirmed that relational capital measurement deserves more investigation and research in a context of supply chain management. The results provide the support for the importance of supply chain relational capital and allow to identify its main elements as follows: mutual trust and respect, close interaction, reciprocity and commitment (Table 7). All of them are reflected in the proposed definition of the relational capital. The study extends knowledge and ensures a richer understanding of how organisations might exploit buyer-supplier relational capital in supply chain management. The significance of RC management increases clearly and consistently in the business environment of the $21^{\text {st }}$ century, because of its growing influence on supply chain performance in many dimensions (e.g. costs, quality, flexibility, innovativeness, resilience, social and environmental responsibility).

The paper provides both theoretical and managerial implications. First, based on the in-depth literature review, the most common items used for defining and evaluating relational capital were identified. These items should be treated by managers as key dimensions of building and improving business relationships with suppliers and clients. Managers should measure the value of relational capital as an intangible asset that is co-created by supply chain links and has relevant effects on companies' value growth and finally, on their competitive advantage. Furthermore, it was recognised that there is a missing quantitative measures of relational capital. Proposals for measures may include: number of joint projects aiming at synergy effects (including knowledge transfer, information sharing, collaborative innovation development), value of assets shared in supply chain (e.g. production lines, warehouses, technologies), percentage of jointly received patents or number of joint initiatives in risk management. The RC measurement will take on especially the increased importance for firms that invest time and money to build and sustain their networks of suppliers or customers and to develop relationships with them. A quantitative approach has become crucial in the era of companies' value management based on intangible assets facing the challenge to deliver value to internal as well as external stakeholders, and particularly important for managers who are aware of the significance of relational capital for improving supply chain performance. In the face of this gap, the further investigation in this regard should be conducted.

There are some limitations of the conducted research. Mainly, the further validation of the proposed measurement approach is necessary to advance and develop a reliable reference for relational capital measurement. It is suggested to carry out additional in-depth literature analysis for each of the five items proposed in the approach. Subsequently, it is necessary to test the validity of the construct using statistical analysis. This requires further quantitative research.

\section{ACKNOWLEDGEMENTS}

Sections 2, 4, 6 are the result of the project "Flexibility in relationships with suppliers in terms of supplier-purchaser models of cooperation on product development in the B2B market", no. 2016/21/B/HS4/00665, that is financed by the National Science Centre (NCN) in Poland.

\section{REFERENCES}

Aaltonen, K., and Turkulainen, V. (2018). Creating relational capital through socialization in project alliances. International Journal of Operations and Production Management, https://doi.org/10.1108/JOPM-02-2017-0091.

Blonska, A., Storey, Ch., Rozemeijer, F., Wetzels, M., and De Ruyter, K. (2013). Decomposing the effect of supplier development on relational benefits: The role of relational capital. Industrial Marketing Management 42, pp. 1295 1306.

Capello, R. (2002). Spatial and sectoral characteristics of relational capital in innovation activity. European Planning Studies 10 (2), pp. $177-200$.

Capello, R., and Faggian, A. (2005). Collective learning and relational capital in local innovation processes. Regional Studies 39 (1), pp. $75-87$.

Carey, S., Lawson, B., and Krause, D.R. (2011). Social capital configuration, legal bonds and performance in buyer-supplier relationships. Journal of Operations Management 29, pp. 277 -288 .

Chang, K.H., and Gotcher, D.F. (2007). Safeguarding investments and creation of transaction value in asymmetric international subcontracting relationships: The role of relationship learning and relational capital. Journal of World Business 42, pp. 477 -488 .

Chen, Y.S., James Lin, M.J., and Chang, C.H. (2006). The influence of intellectual capital on new product development performance-the manufacturing companies of Taiwan as an example. Total Quality Management and Business Excellence 17 (10), pp. 1323 - 1339.

Christopher, M. (2011), Logistics \& Supply Chain Management, Pearson Education, Harlow 2011.

Ciszewska-Mlinarič, M., Obłój, K., and Mlinarič, F. (2012). How relational capabilities matter? Organizational context and performance of internationally oriented SMEs. Central Europe Business Review 1 (3), pp. 28 - 36.

Cousins, P.D., Handfield, R.B., Lawson, B., and Petersen, K. J. (2006). Creating supply chain relational capital: The impact of formal and informal socialization processes. Journal of operations Management 24 (6), pp. $851-863$.

Crosby, L.A., Evans, K.R., and Cowles, D. (1990). Relationship quality in services selling: an interpersonal influence perspective. The Journal of Marketing 54 (3), pp. 68 - 81.

Crosby, L.A., and Taylor, J.R. (1983). Psychological commitment and its effects on post-decision evaluation and preference stability among voters. Journal of Consumer Research 9 (4), pp. $413-131$.

De Clercq, D., and Sapienza, H.J. (2006). Effects of relational capital and commitment on venture capitalists' perception of portfolio company performance. Journal of Business Venturing 21 (3), pp. 326 - 347.

Dorrego, P.F., Costa, R.V., and Fernández, C.F.-J. (2013). Product Innovation and Relational Capital: Evidence from Portugal. The Electronic Journal of Knowledge Management 11 (4), pp. $295-308$.

Dyer, J.H., and Singh, H. (1998). The relational view: cooperative strategy and sources of interorganizational competitive 
advantage. The Academy of Management Review 23 (4), pp. $660-679$.

Fichman, M. and Levinthal, D.A. (1991). Honeymoons and the liability of adolescence: a new perspective on duration dependence in social and organizational relationships. Academy of Management Review 16 (2), pp. $442-468$.

Granovetter, M. (1992). Problems of explanation in economic sociology. In: N. Noria, R. Eccles (ed.), Networks and organizations: structure, form and action. Harvard Business School Press, Boston, MA, pp. $25-56$.

Gupta, A.K., and Govindarajan, V. (2000). Knowledge flows within multinational corporations. Strategic Management Journal March, pp. $473-496$.

Hammervoll, T. (2011). Honeymoons in supply chain relationships: The effects of financial capital, social capital and psychological commitment. The International Journal of Logistics Management 22 (2), pp. 264 - 279.

Hoppner, J.J., and Griffith, D.A. (2011). The role of reciprocity in clarifying the performance payoff of relational behaviour. Journal of Marketing Research 48 (5), pp. 920 - 928.

Hsu, C.C., Tan, K.C., Laosirihongthong, T., and Leong, G.K. (2011). Entrepreneurial SCM competence and performance of manufacturing SMEs. International Journal of Production Research 49 (22), pp. $6629-6649$.

Huikkola, T., Ylimäki, J., and Kohtamäki, M. (2013). Joint learning in $R \& D$ collaborations and the facilitating relational practices. Industrial Marketing Management 42 (7), pp. 1167 $-1180$.

Inkpen, A.C., and Tsang, E.W. (2005). Social capital, networks, and knowledge transfer. Academy of management review 30 (1), pp. $146-165$.

Jer R., Kim D., and Bello D.C. (2017). Relationship-based product innovations: Evidence from the global supply chain. Journal of Business Research 80, pp. 127 - 140.

Jia, F., Rutherford, Ch., and Lamming, R. (2016). Cultural adaptation and socialisation between Western and Chinese suppliers: The formation of a hybrid culture. International Business Review 25, pp. 1246 - 1261.

Johnson, N., Elliott, D., and Drake, P. (2013). Exploring the role of social capital in facilitating supply chain resilience. Supply Chain Management: An International Journal 18 (3), pp. 324 -336 .

Kale, P., Singh, H., and Perlmutter, H. (2000). Learning and protection of proprietary assets in strategic alliances: Building relational capital. Strategic Management Journal 21 (3), pp. $217-237$.

Kohtamäki, M., Partanen, J., and Möller, K. (2013). Making a profit with R\&D services - The critical role of relational capital. Industrial Marketing Management 42 (1), pp. 71 - 81.

Krause, D.R., Handfield, R.B. and Tyler, B.B. (2007). The relationships between supplier development, commitment, social capital accumulation and performance improvement. Journal of Operations Management 25 (2), pp. 528 - 545.

Kulangara, N.P., Jackson, S.A. and Prater, E. (2016). Examining the impact of socialization and information sharing and the mediating effect of trust on innovation capability. International Journal of Operations \& Production Management 36 (11), pp. 1601 - 1624.

Lawson, B., Tyler B.B. and Cousins, P.D. (2008). Antecedents and consequences of social capital on buyer performance improvement. Journal of Operations Management 26, pp. 446-460.

Lee, S.Y. (2015). The effects of green supply chain management on the supplier's performance through social capital accumulation. Supply Chain Management: An International Journal 20 (1), pp. $42-55$.

Léger, P.M. (2010). Interorganizational IT investments and the value upstream relational capital. Journal of Intellectual Capital 11 (3), pp. 406 - 428.

Lorenzoni, G., and Lipparani, A. (1999). The leveraging of interfirm relationships as a distinctive organizational capability: a longitudinal study. Strategic Management Journal 20 (4), pp. 317 - 338.

Morgan, R.M. and Hunt, S.D. (1994). The commitment-trust theory of relationship marketing. The Journal of Marketing 58 (3), pp. $20-38$.

Mousavi, Z. and Takhtaei, N., (2012). The Impact Of Intellectual Capital Disclosure On Capital Markets: An Overview. Editorial Note 201 Profile of Authors Included in this Number 202 Information for Contributors, 2045 (2), pp. 267 - 270.

Mubarik, S., Chandran, V.G.R., and Devadason, E.S. (2016). Relational capital quality and client loyalty: firm-level evidence from pharmaceuticals, Pakistan. The Learning Organization 23 (1), pp. $43-60$.

Nahapiet, J., and Ghoshal, S. (1998). Social capital, intellectual capital, and the organizational advantage. Academy of Management Review 23 (2), pp. 242 - 266.

Nielson, C.C. (1998). An empirical examination of the role of "closeness" in industrial buyer-seller relationships. European Journal of Marketing 32 (5/6), pp. 441 - 463.

Palmatier, R.W., Dant, R.P., and Grewal, D. (2007). A comparative longitudinal analysis of theoretical perspectives of interorganizational relationship performance. Journal of Marketing 71 (4), pp. 172 - 194.

Petersen, K.J., Handfield, R.B., Lawson, B. and Cousins, P.D. (2008). Buyer dependency and relational capital formation: the mediating effects of socialization processes and supplier integration. Journal of Supply Chain Management 44 (4), pp. $53-65$.

Pfeffer, J. and Salancik, G. (2003), The External Control of Organisations: A Resource Dependence Perspective, Stanford University Press, Stanford. In: Kulangara, N.P., Jackson, S.A., and Prater, E. (2016). Examining the impact of socialization and information sharing and the mediating effect of trust on innovation capability. International Journal of Operations \& Production Management 36 (11), pp. 1601 $-1624$.

Preston, D.S., Chen, D.Q., Swink, M., and Meade, L. (2017). Generating Supplier Benefits through Buyer-Enabled Knowledge Enrichment: A Social Capital Perspective. Decision Sciences 48 (2), pp. 248 - 287.

Roden, S., and Lawson, B. (2014). Developing social capital in buyer-supplier relationships: The contingent effect of relationship-specific adaptations. International Journal of Production Economics 151, pp. 89 - 99.

Sabel, C. (1993). Studied trust: Building new form of cooperation in a volatile economy. Human Relations 46 (9), pp. $1133-$ 1170.

Sambasivan, M., Siew-Phaik, L., Mohamed, Z.A., and Leong, Y.Ch. (2013). Factors influencing strategic ourcomes in a manufacturing supply chain: Role of alliance motives, interdependence, asset specificity and relational capital. International Journal of Production Economics 141, pp. 339 -351 .

Tranfield, D., Denyer, D., and Smart, P. (2003). Towards a methodology for developing evidence-informed management knowledge by means of systematic review. British Journal of Management 14 (3), pp. 207 - 222.

Verwaal, E. (2017). Global outsourcing, explorative innovation and firm financial performance: A knowledge-exchange based perspective. Journal of World Business 52 (1), pp. 17 - 27.

Villena, V.H., Revilla, E., and Choi, T.Y. (2011). The dark side of buyer-supplier relationships: A social capital perspective. Journal of Operations Management 29 (6), pp. 561 - 576.

Whipple, J.M., Wiedmer, R., and Boyer, K.K. (2015). A dyadic investigation of collaborative competence, social capital, and performance in buyer-supplier relationships. Journal of Supply Chain Management April, pp. 3 - 20.

Yi, Y., Li, Y., Hitt, M.A., Liu, Y., and Wei, Z. (2016). The influence of resource bundling on the speed of strategic change: 
Moderating effects of relational capital. Asia Pacific Journal of Management 33, pp. 435 - 467.

Yim, B., and Leem, B. (2013). The effect of the supply chain social capital. Industrial Management \& Data Systems 113 (3), pp. $324-349$.
Youndt, M., Subramaniam, M., and Snell, S.A. (2004). Intellectual Capital Profiles: An Examination of Investments and Returns. Journal of Management Studies 41, pp. 335 - 361.

Dr. Barbara Ocicka, assistant professor in Department of Logistics at SGH Warsaw School of Economics. Assistant to the Chief of both Postgraduate Studies in Logistics and Supply Chain Management as well as Postgraduate Studies in Purchasing and Supply Management. Faculty Council Member of the Collegium of Business Administration at SGH. PhD in Economics in the field of supply chain management. Researcher within ChemMultimodal Project: Promotion of multimodal transport in chemical logistics - Interreg Central Europe (2017-2019) and BestLog Project: Best practices in logistics and supply chain management - EU $6^{\text {th }}$ Framework Programme (2006-2010). Author and co-author of over 50 publications on megatrends vs supply chain management, strategies of global supply chains' reconfiguration, digital technologies in logistics and supply chain management, purchasing, supply management and sourcing strategies, best practices in logistics and supply chain management. Her latest book is entitled "The role of purchasing in business" (2019).

Dr. Grażyna Wieteska, master degree in Environmental Protection. She completed postgraduate studies in the field of the Occupational Health and Safety as well as the postgraduate studies in the field of Cosmetology at the Faculty of Biotechnology and Food Sciences at the Lodz University of Technology. She has got several years of business experience with a huge commitment to B2B relationship management. PhD in Economic Sciences in the field of Management Sciences. Employed at the Faculty of Management at the University of Lodz, also lecturer in the area of logistics and supply chain management, organizational standards, audits on MBA programs, postgraduate studies, full and part time studies in Poland and abroad. Involved in many research and educational projects performed in cooperation with European universities. Author and coauthor of over fifty publications on risk management, supply chain resilience, sustainable development and product development. 